\title{
Gambaran Penerapan Perawat Dalam Melakukan Program Kesehatan dan Keselamatan Kerja Di Rumah Sakit
}

\author{
SELLY FEBI MARGARETHA PANGGABEAN
}

$\underline{\text { sellyfebi2601@gmail.com }}$

\section{LATAR BELAKANG}

Rumah sakit merupakan salah satu tempat kerja, yang wajib melaksanakan Program Keselamatan dan Kesehatan Kerja Rumah Sakit (K3RS) yang bermanfaat baik bagi SDM Rumah Sakit. Rumah sakit juga dituntut harus melaksanakan dan mengembangkan program Kesehatan dan Keselamatan Kerja di Rumah sakit (K3RS) seperti yang tercantum dalam buku Standar Pelayanan Rumah Sakit dan terdapat dalam instrumen akreditasi Rumah sakit. Oleh karena itu, Rumah sakit dituntut untuk melaksanakan Upaya Kesehatan dan Keselamatan Kerja (K3) yang dilaksanakan secara terintegrasi dan menyeluruh sehingga risiko terjadinya Penyakit Akibat Kerja (PAK) dan Kecelakaan Akibat Kerja (KAK) di Rumah sakit dapat dihindari. Sebagai faktor penyebab, sering terjadinya angka kecelakaan dan penyakit akibat kerja, terjadi karena kurangnya kesadaran pekerja dan kualitas dan keterampilan pekerja yang kurang memadai, serta banyak pekerja yang meremehkan risiko kerja, sehingga tidak menggunakan alat - alat pengaman walaupun sudah tersedia. Sehingga sasaran utama K3RS adalah tenaga medis, tenaga non medis, pasien, pengunjung / pengantar pasien, serta lingkungan sekitar Rumah sakit.

Program Keselamatan dan Kesehatan Kerja yang tertulis menurut Keputusan Menteri Kesehatan RI No.1087/MENKES/SK/VIII/2010 sebagai berikut : pengembangan kebijakan K3RS, pembudayaan perilaku K3RS, pengembangan SDM K3RS, pengembangan pedoman, petunjuk teknis dan standard operational procedure (SOP) K3RS, pemantauan dan evaluasi kesehatan lingkungan tempat kerja, pelayanan kesehatan kerja, pelayanan keselamatan kerja, pengembangan program pemeliharaan pengelolaan limbah padat, cair dan gas, pengelolaan jasa, bahan beracun berbahaya dan barang berbahaya, pengembangan manajemen tanggap 
darurat, pengumpulan, pengolahan, dokumentasi data dan pelaporan kegiatan $\mathrm{K} 3$, dan review progam tahunan. Keberhasilan program Kesehatan dan Keselamatan Kerja (K3) di Rumah sakit tidak lepas dari sikap kepatuhan personal baik dari pihak perawat maupun pihak manajemen atas dalam melaksanakan peraturan dan kebijakan peraturan K3 untuk mendukung pencapaian zero accident di rumah sakit.

Pelaksanaan Keselamatan dan Kesehatan Kerja (K3) adalah salah satu bentuk upaya untuk menciptakan tempat kerja yang aman, sehat, bebas dari pencemaran lingkungan, sehingga dapat mengurangi dan bebas dari kecelakaan kerja dan penyakit akibat kerja yang pada akhirnya dapat meningkatkan efisiensi dan produktivitas kerja. Peningkatan pemahaman terhadap K3 di tempat kerja dapat melalui pembandingan persepsi pekerja terhadap top manajemen, dimana sebenarnya standard dan aturan yang relevan akan membantu top manajemen untuk memberi arahan secara persuasif tentang faktor praktik kerja yang berisiko kecelakaan. Perilaku K3 akan tumbuh dari adanya feedback (umpan balik) dari kejadian yang dianggap akan menimbulkan kecelakaaan, sehingga dapat diketahui usaha antisipasi terhadap akibat yang akan datang, dan bermanfaat bagi pembelajaran organisasi dalam peningkatan Kesehatan dan Keselamaytan Kerja (K3).

\section{METODE}

Dalam kajian ini, metode yang digunakan oleh penulis adalah kajian bebas (literature review), dengan cara membaca, menganalisis, menyimpulkan kajian jurnal online, textbook, e-book, serta buku pedoman yang terkait dengan pokok bahasan dari kajian yakni gambaran pelaksanaan dan penerapan dalam melakukan program kesehatan dan keselamatan kerja di rumah sakit. Dengan menggunakan jurnal dan referensi yang digunakan pada kajian bebas (literature review) ini dengan tahun terbit paling lama 2012, dengan jumlah minimal 10 referensi.

\section{HASIL}

Berdasarkan hasil analisis yang dapat disimpulkan dari berbagai sumber (literature review) bahwa tingkat pengetahuan perawat, faktor perilaku perawat dan penerapan pelayanan kesehatan kerja yang dilakukan perawat dalam penerapan K3 sangatlah penting untuk tercapainya keselamatan pasien, kepuasan pasien, dapat mengurangi angka kecelakaan ditempat kerja serta menjaga keselamatan dilingkungan Rumah sakit. Adapun beberapa jurnal yang disimpulkan terkait dengan $\mathrm{K} 3$ yaitu : 
Jurnal Pertama, Hubungan Pengetahuan Dengan Upaya Penerapan K3 Pada Perawat Vol.1 No.1 Tahun 2017. Menurut hasil analisis dari jurnal tersebut, dapat disimpulkan bahwa mayoritas yang memiliki tingkat pengetahuan K3 yang cukup terdapat (61\%) dan mayoritas yang memiliki upaya penerapan K3 yang baik terdapat (68 \%), serta disimpulkan juga faktor yang dapat mempengaruhi tingkat pengetahuan K3 pada penelitian adalah Pendidikan, usia, dan lama kerja. Hal ini menunjukkan bahwa pendidikan yang tinggi dapat meningkatkan pengetahuan seseorang. Oleh sebab itu, semakin tinggi pendidikan seseorang, pengetahuan yang dimilikinya akan semakin baik.

Jurnal Kedua, Perilaku Perawat Dalam Penerapan Manajemen Kesehatan Dan Keselamatan Kerja (K3) Di Aceh Vol.VIII No. 3 Tahun 2017. Menurut hasil analisis dari jurnal tersebut, dapat disimpulkan dari faktor perilaku perawat sebagian besar, perawat pelaksana memiliki perilaku yang baik dalam Penerapan Manajemen Kesehatan dan Keselamatan Kerja (K3) baik ditinjau dari faktor internal terdapat (52,5\%) dan faktor eksternal (58,8\%). Berdasarkan asumsi peneliti bahwa faktor internal pada perilaku perawat berada pada kategori baik diantaranya persepsi.

Jurnal Ketiga, Penerapan Pelayanan Kesehatan Dan Keselamatan Kerja Pada Perawat IGD Rumah Sakit Umum Dr. Wahidin Sudiro Husodo Mojokerto Tahun 2017 Vol.16 No.1. Menurut hasil analisis dari jurnal tersebut, dapat disimpulkan dari Penerapan Pelayanan Kesehatan Kerja yang diterima oleh perawat IGD sebesar 8 variabel $(80 \%)$ telah memenuhi syarat, 1 variabel (10\%) cukup memenuhi syarat dan 1 variabel (10\%) kurang memenuhi syarat. Hal ini dapat disimpulkan bahwa lebih banyak yang telah melakukan Penerapan Pelayanan Kesehatan dan Keselamatan Kerja (K3) dengan baik sampai mencapai angka presentase sampai $80 \%$.

\section{PEMBAHASAN}

Menurut WHO yang dilansir di KMK RI No. 1087/ MENKES/ SK/ VII/ 2010 dikatakan bahwa Kesehatan Kerja merupakan program yang bertujuan untuk peningkatan dan pemeliharaan derajat fisik, mental dan sosial yang setinggi - tingginya bagi pekerja di semua jenis pekerjaan, pencegahan terhadap gangguan kesehatan pekerja yang disebabkan oleh kondisi pekerjaan; perlindungan bagi pekerja dalam pekerjaannya dari risiko akibat faktor yang merugikan kesehatan; dan penempatan serta pemeliharaan pekerja dalam suatu lingkungan kerja yang disesuaikan dengan kondisi fisiologi dan psikologisnya. Sehingga, menurut KMK RI No. 1087/ MENKES/ SK/VII/ 2010 Kesehatan dan Keselamatan Kerja 
(K3) adalah upaya untuk memberikan jaminan keselamtan dan meningkatkan derajat kesehatan pekerja dengan cara pencegahan kecelakaan dan Penyakit Akibat Kerja (PAK), pengendalian bahaya ditempat kerja, promosi kesehatan, pengobatan dan rehabilitasi.

K3 pada umumnya bertujuan melindungi keselamatan dan kesehatan pekerja ataupun buruh dalam mewujudkan produktivitas kerja yang optimal. Pengetahuan K3RS yang baik diharapkan mampu menekan angka kecelakaan kerja karena individu tersebut dapat menerapkan tindakan yang sesuai dengan pengetahuan K3 yang dimilikinya. Dalam K3 tenaga medis, juga harus menerapkan cara berkomunikasi, dimana komunikasi keselamatan dan kesehatan kerja tersebut dapat menggunakan berbagai media baik lisan maupun tulisan. Hal yang perlu diperhatikan dalam komunikasi yaitu efektifitas dalam komunikasi, informasi harus mudah diingat oleh penerima. Disamping untuk menyampaikan perintah dan pengarahan dalam pelaksanaan pekerjaan, komunikasi keselamatan dan kesehatan kerja (K3) digunakan untuk mendorong perubahan perilaku, sehingga pekerja termotivasi untuk bekerja dengan selamat.

Upaya penerapan K3 di Rumah sakit menyangkut tenaga kerja, cara / metode kerja, alat kerja, proses kerja, dan lingkungan kerja yang meliputi peningkatan, pencegahan, pengobatan, dan pemulihan. Tenaga kesehatan yang sering berkontak langsung dengan pasien adalah perawat. Tingkat pengetahuan K3 perawat sangat penting dalam menjaga keselamatan pasien dan diri perawat itu sendiri, karena keduanya memiliki hubungan bermakna antara tingkat pengetahuan perawat dengan tindakan keselamatan terhadap pasien. Oleh sebab itu, pengetahuan perawat mengenai $\mathrm{K} 3$ sangat diperlukan agar penerapan $\mathrm{K} 3$ berjalan dengan optimal.

Dalam Kesehatan dan Keselamatan Kerja ( K3), seorang perawat harus menerapkan persepsi atau proses pencarian informasi yang dilakukan oleh perawat sebelum melakukan suatu tindakan. Persepsi perawat tentang K3 menunjukkan bagaimana perawat mampu mencari tahu tentang pentingnya K3 baik melalui brosur, leaflet, SOP yang disediakan di ruangan maupun media informasi lainnya. Perawat juga dituntut untuk faham bagaimana cara pencegahan kecelakaan serta penanganan yang dapat dilakukan apabila kecelakaan terjadi. Pemahaman tersebut akan menimbulkan persepsi yang baik dalam diri perawat tentang $\mathrm{K} 3$ sehingga hal ini akan meningkatkan perilakunya dalam menjaga keselamatan. Selain persepsi, sikap juga mempengaruhi perilaku perawat ditinjau dari segi faktor internal (Notoadmodjo, 2010). Seorang perawat dalam melaksanakan manajemen K3 harus memiliki sikap yang 
sesuai dengan nilai-nilai kesehatan dimana seluruh nilai positif yang ada dalam dirinya menjadi pendorong perilaku sehat dan menjadi upaya dalam meningkatkan kesehatan dan keselamatan selama bekerja. Selain itu, ada berbagai cara yang dapat dilakukan untuk meningkatkan persepsi, pengetahuan dan sikap perawat dalam menjaga kesehatan dan keselamatan selama bekerja, diantaranya dengan memberikan promosi kesehatan dan pelatihan tentang K3 sehingga hal ini diharapkan mampu merubah perilaku perawat menjadi lebih baik.

Adapun faktor - faktor yang juga sangat mempengaruhi perilaku perawat dalam penerapan manajemen K3 dirumah sakit, yaitu faktor internal dan faktor eksternal Berdasarkan data yang telah dianalisis, bahwa ada banyak faktor yang dapat menentukan perubahan perilaku perawat dari segi faktor eksternal, diantaranya pengalaman. Pengalaman perawat dapat dilihat dari berbagai aspek. Salah satunya adalah masa kerja. Semakin lama masa kerja perawat maka pengalaman yang dimiliki juga semakin meningkat sehingga perilakunya dalam menjaga keselamatan dirinya juga menjadi lebih baik. Selain itu pengalaman juga dapat diperoleh dari berbagai sosialisasi maupun pelatihan tentang $\mathrm{K} 3$ yang dilakukan oleh pihak rumah sakit.

Sebagai tenaga kesehatan, perawat juga disarankan mampu dalam memahami dan menerapkan ruang lingkup K3RS yang mencakup prinsip, program dan kebijakan pelaksanaan K3RS, standar pelayanan K3RS, standar sarana dan prasarana dan peralatan K3RS, pengelolaan barang berbahaya, standar sumber daya manusia K3RS, pembinaan, pengawasan, pencatatan dan pelaporan. Pada kenyataannya, masih banyak ditemukan di lapangan terjadinya kecelakaan akibat kerja yang dilakukan oleh perawat sehingga dapat berefek pada pasien, lingkungan Rumah Sakit, citra Rumah Sakit, dan tenaga kesehatan lainnya termasuk juga perawat itu sendiri. Maka dari itu, diperlukan pemahaman dan penerapan secara nyata bagi perawat. Perawat perlu mengetahui peran apa saja yang dapat diterapkan ketika bekerja di Rumah sakit, terutama pada program K3RS. Pengetahuan ini perlu diterapkan secara berkelanjutan sesuai peraturan dan kebijakan K3, agar terciptanya Kesehatan dan Keselamatan Kerja yang aman, sehingga dapat mengurangi angka risiko kecelakaan kerja serta penyakit akibat kerja.

Maka sebagian besar dari perawat juga harus memiliki pengalaman dan pengetahuan yang baik tentang penerapan $\mathrm{K} 3$, fasilitas yang disediakan serta budaya organisasi yang ada di rumah sakit sudah mengacu pada standar yang telah ditentukan sesuai dengan peraturan 
KEPMENKES RI 2010 dan peran dari rumah sakit khususnya kepala ruang juga sudah berfungsi secara optimal dalam melakukan monitoring dan evaluasi terhadap kinerja perawat dalam menerapkan budaya Kesehatan dan Keselamatan Kerja (K3).

\section{PENUTUP}

Keselamatan dan Kesehatan Kerja merupakan suatu upaya untuk mendapatkan suasana bekerja yang aman, nyaman dan tujuan akhirnya adalah mencapaiproduktivitas setinggi-tingginya. Maka dari itu, K3 mutlak dilaksakan pada setiapjenis bidang pekerjaan tanpa terkecuali. Terutama bagi tenaga kesehatan, selain memiliki hak dan kewajian terdapat juga keputusan menteri bagi tenaga kerjakesehatan. Bagi tenaga kesehatan khususnya perawat, tidak sedikit angka kejadianpenyakit perawat yang disebabkan oleh lingkungan kerja. Sehingga perawat berhak mendapatkan fasilitaskerja yang memadai dan memenuhi standar untuk mendapatkan tenaga kerja yangberstatus kesehatan optimal dan bergizi baik, semangat kerja tinggi serta efisien dan produktif.

\section{DAFTAR PUSTAKA}

Athifah A.N. (2014). Gambaran Budaya Keselamatan Pasien di RSUD Syekh Yusuf Kabupaten Gowa. Makassar. Fakultas Kesehatan Masyarakat Universitas Hassanuddin, 2:48

Desya Nanda Sri Wahyuni, Siti Rukayah. (2018). Gambaran Penerapan Program Kesehatan Dan Keselamatan Serta Faktor Yang Mempengaruhi Pada Perawat Di RSIJ Sukapura Jakarta Utara. Jurnal Persada Husada Indonesia.Vol. 5 No.16 : 1 - 17

Hasbi Ibrahim, dkk.(2017).Gambaran Penerapan Standard Manajemen Keselamatan Dan Kesehatan Kerja Rumah Sakit Di Rumah Sakit Umum Daerah Haji Makkasar. Public Health Science Jounal. Volume 9 Nomor 2 Tahun 2017.

Nida Dini Hanifa, dkk. (2017). Hubungan Pengetahuan Dengan Upaya Penerapan K3 Pada Perawat. Bandung Meeting on Global Medicine \& Health (BaMGMH). Vol. 1 No.1

Nurhidayanti, D. (2017). Penagaruh Pelaksanaan Keselamatan dan Kesehatan Kerja Terhadap Kepuasan Kerja Perawat. JOM FISIP,4 (1), 1-10 
Rahmawati, Ruli. 2017. Gambaran Penerapan Program Kesehatan dan Keselamatan Kerja Rumah Sakit (K3RS) pada Perawat di RSUD Tugurejo Semarang. Semarang: Departemen Ilmu Keperawatan Fakultas Kedokteran Universitas Diponegoro

Riska Nazirah, Yuswardi. (2017). Perilaku Perawat Dalam Penerapan Manajemen Kesehatan Dan Keselamatan Kerja (K3) Di Aceh. Idea Nursing Journal.Vol. VIII No.3

Simamora, R. H. (2011). ROLE CONFLICT OF NURSE RELATIONSHIP WITH PERFORMANCE IN THE EMERGENCY UNIT OF HOSPITALS RSD DR. SOEBANDI JEMBER. The Malaysian Journal of Nursing, 3(2), 23-32. Konsep dasar $\quad$ K3: sehat, kesehatan kerja, risiko \&hazard dalam pemberian asuhan keperawatan (somatik, perilaku, lingkungan, ergonomik, pengorganisasian pekerjaan, budaya kerja

Stinky Renaldo Mongdong, dkk. (2019). Gambaran Pelaksanaan Program Kesehatan Dan Keselamatan Kerja Rumah Sakit (K3RS) Di RSUD Maria Walanda Maramis Kabupaten Minahasa Utara. Jurnal KESMAS, Vol.8 No.7, November 2019

Subhan Zul Ardi, Widodo Hariyono. (2018). Analisa Penerapan Budaya Perilaku Keselamatan dan Kesehatan Kerja di Rumah Sakit. Jurnal Fakultas Kesehatan Masyarakat. Vol. 12,Issue 1 $15-20$

Tatilu,J., Doda, D.V., dkk. (2012). Implementasi Sistem Manajemen Kesehatan Dan Keselamatan Kerja Di Ruang Inap RSUD Dr. Sam Ratulangi Tondano. Jurnal Fakultas KedokteranUniversitas Sam Ratulangi, 2(2), 60-71.

Utarini, A, Djasri, H. (2012).Keselamatan pasien dan Mutu Pelayanan kesehatan. Jurnal Manajemen Pelayanan Kesehatan. 159- 160.

Widiwati Rinjani Octavia, dkk. (2018). Penerapan Pelayanan Kesehatan Dan Keselamatan Kerja Pada Perawat IGD Rumah Sakit Umum Dr. Wahidin Sudiro Husodo Mojokerto Tahun 2017. Jurnal Gema Kesehatan Lingkungan. Vol. 16 No. 1 
